\title{
Chest pain in rubber chemical workers exposed to carbon disulphide and methaemoglobin formers
}

\author{
L CHRISTINE OLIVER ${ }^{1}$ AND R P WEBER ${ }^{2}$ \\ From the Pulmonary Unit, Massachusetts General Hospital,' Harvard Medical School, ' and Harvard \\ University, ${ }^{2}$ Boston, Mass, USA
}

\begin{abstract}
A cross sectional prevalence study of chest pain in 94 rubber chemical workers exposed to carbon disulphide $\left(\mathrm{CS}_{2}\right)$ and methaemoglobin forming aromatic amines was carried out. The purpose of the study was to determine whether the prevalence of chest pain or coronary heart disease (CHD), or both, in exposed individuals exceeded that of a group of non-exposed individuals from the same plant. Cardiovascular, smoking, and occupational histories were obtained. Blood pressure, height, weight, serum cholesterol, and fasting blood glucose were measured. Resting electrocardiograms (ECGs) were obtained on all study participants, as were exercise stress tests on selected exposed individuals. Matching eliminated important known risk factors for coronary artery disease. Both chest pain and angina were significantly related to exposure, controlling for age and cigarette smoking. This association was not dependent on duration of exposure as defined by 10 or more years of employment in the department of interest. CHD as defined by angina, a history of myocardial infarction, or a coronary ECG or a combination of these occurred more frequently among exposed workers. The number of abnormal ECGs in the exposed group was twice that in the control group, but the difference was not statistically significant. Age rather than exposure appeared to be the important variable associated with raised blood pressure. Neither biological measures of exposure nor ECGs showed an acute effect of workplace exposures on the myocardium. Possible additive or multiplicative effects of individual chemical agents could not be evaluated. Appropriate modification of medical surveillance of rubber chemical workers with exposure to $\mathrm{CS}_{2}$ and aromatic amines is warranted.
\end{abstract}

Complaints of chest pain among a group of workers in a rubber chemical plant in the north eastern United States prompted the present study. In the department (A) in which the symptom occurred employees work with raw materials used in the production of an antioxidant and an accelerator. These raw materials are principally carbon disulphide $\left(\mathrm{CS}_{2}\right)$ and the methaemoglobin formers aniline, orthotoluidine, and nitrobenzene. $\mathrm{CS}_{2}$ and aromatic amines have been in use since plant production began in the early 1950 s.

Coronary artery disease has been associated with chronic exposure to $\mathrm{CS}_{2} .^{1-5}$ Acute adverse effects on the heart may occur as a result of exposure to methaemoglobin formers because of reduced oxygen supply to the myocardium. ${ }^{6}$ The purpose of the present study was to determine (1) the preval-

Received 20 January 1983

Accepted 6 June 1983 ence of chest pain in $A,(2)$ the prevalence of coronary heart disease (CHD) in $A,(3)$ whether either prevalence exceeded the expected, and (4) whether the chest pain reported was the result of acute or chronic effects of workplace exposures, or both.

There are no reports in the English language of excess cardiovascular mobidity and mortality in rubber chemical workers exposed to $\mathrm{CS}_{2}$ but an increased prevalence of cardiovascular disease has been reported in viscose rayon textile workers exposed to $\mathrm{CS}_{2}$. Tiller et al carried out one of the early controlled studies of the effects of long term exposure to relatively low levels of $\mathrm{CS}_{2}{ }^{1}$ and found that the death rate for CHD among men aged 45 to 64 working in the spinning department of a viscose rayon factory exceeded the expected by a factor of 2 in those with more than ten years employment. Comparing a group of Finnish viscose rayon workers with a group of controls, Hernberg $e t a l^{2}$ and Tolonen $e a^{35}$ found an increased death rate from CHD 
and an increase in the relative risk for non-fatal myocardial infarctions $(2 \cdot 8)$ and angina pectoris $(2 \cdot 2)$. The period prevalence rate for ischaemic heart disease observed by Sakurai ${ }^{4}$ in a group of viscose rayon workers exceeded that of a control group by a factor of $2 \cdot 3$. The prevalence of CHD among workers exposed to $\mathrm{CS}_{2}$ in other industrial settings has not been reported.

Animal studies have shown atherosclerotic changes in coronary blood vessels ${ }^{78}$ and the aorta in association with exposure to $\mathrm{CS}_{2}$ but the mechanism is not clear. Wronska-Nofer and Parke report a $60 \%$ increase in the influx of cholesterol from the blood into the aortic wall in rats exposed to $\mathrm{CS}_{2}{ }^{.}{ }^{.}$These authors suggest that $\mathrm{CS}_{2}$ may act to increase the permeability of the aortic wall to cholesterol. Visconti observed a decrease in the fibrinolytic activity of plasmin and plasminogen in 57 workers exposed to $\mathrm{CS}_{2}$ compared with a group of controls. ${ }^{10}$ The inhibitory effect on plasmin was possibly related to duration of exposure. Other factors such as diet also seem to be important. Wronska-Nofer $e t$ al found an increase in intracellular and extracellular lipid deposits in the intima and media of the aorta, in the walls of coronary vessels, and in the endocardium in rabbits inhaling low levels of $\mathrm{CS}_{2}$ and eating a high cholesterol diet. ${ }^{8}$ By contrast with his findings in Finnish textile workers, Tolonen found no increase in prevalence of high blood pressure, angina, and "coronary" electrocardiograms (ECG) in a group of Japanese viscose rayon workers compared with a group of controls. "The diet of the Finns is generally higher in cholesterol than that of the Japanese.

\section{Methods}

A cross sectional prevalence study was carried out in October 1980. At that time the plant employed about 250 production and 51 maintenance workers in two departments. The other department produced vinyl chloride polymer. The study population consisted of all employees working in department $\mathbf{A}$ at the time of the study and for at least one month before that time. The control group consisted of employees at the plant who were not working in A at the time of the study and who had not worked there during the preceding year or for more than six months in total. This group was selected by matching for age, sex, and race.

Participation was on a volunteer basis. Of 95 potentially exposed workers, 94 (98.9\%) participated; of the 89 selected controls, ${ }^{*} 87(97 \cdot 7 \%)$ participated. After completion of the study, a review of work histories resulted in reclassification of some

*A match was not found for six exposed workers because of the limited number of possible controls. individuals with regard to exposure status. Six controls were reclassified as exposed and one control and one exposed could not be classified at all because of inadequate work histories. A group of "intermediately exposed" workers was designated. This group was defined as "not in A now but there within the past year or for more than six months in total, in A warehouse with no history of work in another part of $A$, and in maintenance with mixed or indeterminant exposures." Fifteen controls and 10 exposed workers were reclassified as intermediate. $\dagger$ The final exposed group thus consisted of 89 individuals and the control group of $65 ; 25$ were in the intermediate group.

A medical screen and industrial hygiene survey were carried out. The following medical tests were performed: a questionnaire consisting of occupational, medical, cardiovascular, and smoking histories; height, weight, and sitting and supine blood pressure measurements; resting standard 12 lead ECG; and serum cholesterol concentration. The cardiovascular questionnaire was a modification of the Rose $^{12}$ angina questionnaire. Three physicians administered cardiovascular and smoking histories without knowledge of exposure status. The remainder of the questionnaire was self administered. ECGs were interpreted without knowledge of exposure status by a board certified cardiologist. Two physicians independently evaluated cardiovascular histories without knowledge of exposure status and designated chest pain as definitely, possibly, or not angina.

Twenty nine workers had treadmill exercise stress tests performed as part of a follow up evaluation. Twenty six were from the exposed group and three from the intermediately exposed group. These were individuals in whom CHD was suspected but not diagnosable by previous test results. Each was in one of the following categories: (1) possible angina, normal resting ECG; (2) possible angina, abnormal non-diagnostic ECG; and (3) not angina, abnormal non-diagnostic ECG.

Urinary aromatic amines and p-nitrophenol levels were obtained as a measure of subacute/chronic exposure to aniline, $o$-toluidine, and nitrobenzene. Whole blood methaemoglobin levels were obtained as a measure of acute exposure to these chemicals. Analyses for methaemoglobin were carried out within four hours of sample collection.

All screening tests were done during the work shift. For logistical reasons, blood samples for methaemoglobin were obtained one month after other tests were completed. It was assumed that the principal work area for an individual did not change

+Because their exposure status was ambiguous, the intermediate group was not included in the final analysis. 
during the intervening month.

The industrial hygiene survey included area and personal samples analysed for $\mathrm{CS}_{2}$, hydrogen sulphide $\left(\mathrm{H}_{2} \mathrm{~S}\right)$, aniline, nitrobenzene, and $o$-toluidine. Personal samples on production workers were collected for a five to seven hour period.

Exposed and control groups were each divided into two subgroups with regard to duration of work at the plant: those with 10 or more years and those with less than 10 years. The prevalence of chest pain, angina, ECG abnormalities, raised blood pressure, and history of myocardial infarction (MI) were computed for each subgroup. To determine better the true prevalence of CHD in each subgroup, we defined CHD as the presence of possible/definite angina, a coronary ECG, or a history of MI or a combination of these. A coronary ECG was defined as one with ST-T segment abnormalities consistent with ischaemia or $\mathrm{Q} / \mathrm{T}$ wave abnormalities consistent with a previous MI, or both.

In an attempt to define exposures more accurately, A was divided into three work areas: raw materials, reacted products, and total work area. The assumption was made that the highest levels of exposure to the chemicals of interest would occur where the raw materials were handled. This assumption was tested by the industrial hygiene measurements and by a correlation of biological monitoring results with work area. To evaluate the association between any acute effects on the myocardium and exposures, the results of the cardiovascular histories and resting ECGs were correlated with mean aromatic amine and methaemoglobin (\% saturation) levels.

\section{Statistical analysis}

Student $t$ test was used to measure the effectiveness of matching in eliminating as confounders known important risk factors for coronary artery disease. The Chi-square statistic was used to assess the strength of the association between exposure and chest pain, exposure and angina, and ECG abnormalities and the results of biological monitoring. Log linear statistical models and hierarchical hypothesis testing were used to assess the relationship between chest pain and angina and exposure, controlling for age and cigarette smoking. Log linear analysis was also used to assess the association of chest pain, angina, blood pressure elevation, coronary ECG, and CHD with duration of exposure. Analysis of variance (ANOVA) was used to compare mean aromatic amine and methaemoglobin levels in the exposed group with the control group, both in general and with regard to specific work areas. ANOVA was also used to evaluate the association between mean aromatic amine and methaemoglobin levels and chest pain/angina in the exposed and control groups.

\section{Results}

Matching eliminated important known risk factors for CHD (table 1). The mean total serum cholesterol for the exposed group was $208 \mathrm{mg} / 100 \mathrm{ml}$ and for the control group, $214 \mathrm{mg} / 100 \mathrm{ml}$; mean fasting blood glucose was $126 \mathrm{mg} / 100 \mathrm{ml}$ and $113 \mathrm{mg} / 100$ $\mathrm{ml}$ for exposed and controls, respectively. There is an association of both chest pain and angina with exposure that achieves statistical significance (table 2). Forty five of the 89 exposed men and 13 of the 65 controls reported chest pain. Seven of the exposed and three of the controls were classified as angina, 16 exposed and two controls as possible angina. Two exposed could not be classified with regard to angina because of incomplete questionnaires.

Log linear statistical models and hierarchical hypothesis testing show that the association of chest pain and angina with exposure persists after controlling for age and cigarette smoking (tables 3 and 4). This analytical method is a statistical technique for analysing data arranged in contingency tables. ${ }^{13-17}$ It (1) gives estimates of the observed cell frequencies (based on marginal and conditional odds ratios) under different models or hypotheses; (2) permits the testing of the adequacy of alternative models; and (3) permits the exploration and testing of complex relationships among several variables.

Some basic terms in log linear analysis and hierarchical hypothesis testing require definition. The term "effect" refers to a relationship between a variable, or combination of variables, and the observed cell frequencies. That is, an effect is a relationship which must be taken into account in order to explain

Table 1 Cardiovascular risk factors

\begin{tabular}{|c|c|c|c|}
\hline & \multicolumn{3}{|c|}{ (mean values) } \\
\hline $\begin{array}{l}\text { Major } \\
\text { Age (y) }\end{array}$ & 37.64 & 37.85 & \\
\hline Blood pressure: & & & \\
\hline $\begin{array}{l}\text { Systolic (supine) } \\
\text { Diastolic (supine) } \\
\text { History of hypertension }\end{array}$ & $\begin{array}{c}129 \cdot 0 \\
80 \cdot 6 \\
19\end{array}$ & $\begin{array}{c}130 \cdot 5 \\
81 \cdot 5 \\
14\end{array}$ & $\begin{array}{l}p=0.58 \\
p=0.59 \\
p=0.90\end{array}$ \\
\hline Cigarette smoking: & & & \\
\hline $\begin{array}{l}\text { Total pack years } \\
\text { No/day } \\
\text { Minor }\end{array}$ & $\begin{array}{l}14 \cdot 8 \\
27 \cdot 33\end{array}$ & $\begin{array}{c}9 \cdot 6 \\
23 \cdot 27\end{array}$ & $\begin{array}{l}p=0.09 \\
p=0.06\end{array}$ \\
\hline $\begin{array}{l}\text { Height (ins) } \\
\text { Weight (lbs) } \\
\text { Family history, heart disease }\end{array}$ & $\begin{array}{r}70 \cdot 53 \\
173 \cdot 03 \\
27\end{array}$ & $\begin{array}{c}68 \cdot 76 \\
167 \cdot 32 \\
19\end{array}$ & $\begin{array}{l}p=0.12 \\
p=0.57 \\
p=0.83\end{array}$ \\
\hline Personal history, diabetes mellitus & 3 & 0 & $\mathrm{p}=0.32$ \\
\hline
\end{tabular}


Table 2 Correlation: chest pain and angina with exposure

\begin{tabular}{llll}
\hline & \multicolumn{2}{c}{ Exposed } & \\
\cline { 2 - 3 } & Yes & No & Total \\
\hline Chest pain* & & & \\
Yes & $45(50 \cdot 6)$ & $13(20)$ & $58(37 \cdot 7)$ \\
$\quad$ No & $44(49 \cdot 4)$ & $52(80)$ & $96(62 \cdot 3)$ \\
$\quad$ Total & 89 & 65 & 154 \\
Anginat & $7(8 \cdot 0)$ & $3(4 \cdot 6)$ & $10(6 \cdot 6)$ \\
$\quad$ Yes & $16(18 \cdot 4)$ & $2(3.0)$ & $18(11 \cdot 8)$ \\
Maybe & $64(73 \cdot 6)$ & $60(92 \cdot 3)$ & $124(81 \cdot 6)$ \\
No & 65 & 152 \\
\hline Total & 87 & 65 & \\
\hline
\end{tabular}

$x^{2}=13.67,1 \mathrm{df}, \mathrm{p}=0.0002$

$\dagger \chi^{2}=9 \cdot 64,2 \mathrm{df}, \mathrm{p}=0.008$

$\left(X^{2}\right)=$ Per cent adequately - that is, model or predict-the observed cell frequencies. A "model" or "hypothesis" refers to a particular combination of effects which is believed to account for the observed cell frequencies. This model or hypothesis is then used to generate predicted cell frequencies, which are compared with the observed cell frequencies by a chi square test of statistical significance. It is customary to describe hypotheses or models in terms of "fitted marginals"- that is, marginals of various subtables that are held constant as part of the estimation procedure.

In table 3 the three way interaction effect between chest pain (C), exposure (E), and age (A) is denoted

Table 3 Relationships: exposure, smoking, age, chest pain

\begin{tabular}{|c|c|c|c|c|c|c|c|c|c|}
\hline & \multicolumn{8}{|l|}{ Exposure } & \multirow[t]{2}{*}{ Total } \\
\hline & Yes & & & & No & & & & \\
\hline \multirow{2}{*}{$\begin{array}{l}\text { Age (y) } \\
\text { Smoking: } \\
\text { Chest pain: } \\
\text { Yes } \\
\text { No } \\
\text { Total }\end{array}$} & Low & High & Low & High & Low & High & Low & High & \\
\hline & $\begin{array}{l}12(44.4) \\
15(55 \cdot 6) \\
27(17 \cdot 8)\end{array}$ & $\begin{array}{r}14(70.0) \\
6(30.0) \\
20(13.2)\end{array}$ & $\begin{array}{r}8(36.4) \\
14(63.6) \\
22(14.5)\end{array}$ & $\begin{array}{r}11(57 \cdot 9) \\
8(42 \cdot 1) \\
19(12 \cdot 5)\end{array}$ & $\begin{array}{r}5(18 \cdot 5) \\
22(81 \cdot 5) \\
27(17 \cdot 8)\end{array}$ & $\begin{array}{l}1(14 \cdot 3) \\
6(85 \cdot 7) \\
7(11 \cdot 6)\end{array}$ & $\begin{array}{r}4(25 \cdot 0) \\
12(75 \cdot 0) \\
16(10 \cdot 5)\end{array}$ & $\begin{array}{r}4(28.6) \\
10(71.4) \\
14(9.2)\end{array}$ & $\begin{array}{r}59(38.8) \\
93(61 \cdot 2) \\
152\end{array}$ \\
\hline
\end{tabular}

( ) $=$ Per cent. (Column total percentages do not add to $100 \%$ because of rounding.)

\begin{tabular}{|c|c|c|c|c|c|c|c|c|c|}
\hline Model & & $\begin{array}{l}\text { Chi } \\
\text { Square }\end{array}$ & $d f$ & $p$ & $\begin{array}{l}\text { Term } \\
\text { tested }\end{array}$ & $\begin{array}{l}\text { Model } \\
\text { compared } \\
\text { with }\end{array}$ & $\Delta \chi^{2}$ & $d f$ & $p$ \\
\hline $\begin{array}{l}1 \\
2 \\
3 \\
4 \\
5\end{array}$ & $\begin{array}{l}(\mathrm{EA})(\mathrm{ES})(\mathrm{EC})(\mathrm{AS})(\mathrm{AC})(\mathrm{SC}) \\
(\mathrm{ES})(\mathrm{EC})(\mathrm{AS})(\mathrm{AC})(\mathrm{SC}) \\
(\mathrm{ES})(\mathrm{AS})(\mathrm{AC})(\mathrm{SC}) \\
(\mathrm{EAC})(\mathrm{ES})(\mathrm{AS})(\mathrm{SC}) \\
(\mathrm{ESC})(\mathrm{AS})(\mathrm{AC})\end{array}$ & $\begin{array}{r}4 \cdot 91 \\
4 \cdot 92 \\
17 \cdot 36 \\
3 \cdot 46 \\
3 \cdot 87\end{array}$ & $\begin{array}{l}5 \\
6 \\
7 \\
4 \\
5\end{array}$ & $\begin{array}{l}0.43 \\
0.55 \\
0.02 \\
0.48 \\
0.57\end{array}$ & $\begin{array}{l}(\mathrm{EA}) \\
(\mathrm{CE}) \\
(\mathrm{CEA}) \\
(\mathrm{CES})\end{array}$ & $\begin{array}{l}1 \\
2 \\
1 \\
2\end{array}$ & $\begin{array}{r}0.00 \\
12.44 \\
1.45 \\
1.05\end{array}$ & $\begin{array}{l}1 \\
1 \\
1 \\
1\end{array}$ & $\begin{array}{l}0.98 \\
0.00 \\
0.23 \\
0.31\end{array}$ \\
\hline
\end{tabular}

$\mathrm{E}=$ Exposure.

$\mathrm{C}=$ Chest pain.

$\mathrm{S}=$ Smoking

A $=$ Age.

Table 4 Relationships: angina, age, smoking, exposure

\begin{tabular}{|c|c|c|c|c|c|c|c|c|c|}
\hline & Exposed & & & & Control & & & & \\
\hline $\begin{array}{l}\text { Age (y) } \\
\text { Smoking: } \\
\text { Angina: }\end{array}$ & $\begin{array}{l}\leqslant 39 \\
\text { Low }\end{array}$ & High & $\begin{array}{l}>40 \\
\text { Low }\end{array}$ & High & $\begin{array}{l}\leqslant 39 \\
\text { Low }\end{array}$ & High & $\begin{array}{l}>40 \\
\text { Low }\end{array}$ & High & Total \\
\hline $\begin{array}{l}\text { Yes } \\
\text { No } \\
\text { Total }\end{array}$ & $\begin{array}{r}4(14 \cdot 8) \\
23(85 \cdot 2) \\
27(18)\end{array}$ & $\begin{array}{r}10(52 \cdot 6) \\
9(47 \cdot 4) \\
19(12 \cdot 7)\end{array}$ & $\begin{array}{r}4(18 \cdot 2) \\
18(81 \cdot 8) \\
22(14 \cdot 7)\end{array}$ & $\begin{aligned} 5 & (27 \cdot 8) \\
13 & (72 \cdot 2) \\
18 & (12)\end{aligned}$ & $\begin{aligned} 1 & \left(\begin{array}{l}3 \cdot 7) \\
26 \\
27\end{array}\left(\begin{array}{l}96 \cdot 3) \\
18)\end{array}\right.\right.\end{aligned}$ & $\begin{array}{l}0(0) \\
7(100) \\
7(4 \cdot 7)\end{array}$ & $\begin{array}{l}1(6 \cdot 3) \\
15(93 \cdot 7) \\
16(10 \cdot 7)\end{array}$ & 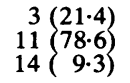 & $\begin{array}{r}28(18 \cdot 7) \\
122(81 \cdot 3) \\
150\end{array}$ \\
\hline
\end{tabular}

( ) $=$ Per cent. (Column total percentages do not add to $100 \%$ because of rounding.)

\begin{tabular}{|c|c|c|c|c|c|c|c|c|c|}
\hline Model & $\cdot$ & $\begin{array}{l}\text { Chi } \\
\text { Square }\end{array}$ & $d f$ & $p$ & $\begin{array}{l}\text { Term } \\
\text { tested }\end{array}$ & $\begin{array}{l}\text { Model } \\
\text { compared } \\
\text { with }\end{array}$ & $\Delta x^{2}$ & $d f$ & $p$ \\
\hline $\begin{array}{l}1 \\
2 \\
3 \\
4 \\
5\end{array}$ & $\begin{array}{l}\text { (EA) (ES) (EAn) (AS) (AAn) (SAn) } \\
\text { ES) (EAn) (AS) (AAn) (SAn) } \\
\text { ES) (AS) (AAn) (SAn) } \\
\text { EAAn) (ES) (AS) (SAn) } \\
\text { ESAn) (AS) (AAn) }\end{array}$ & $\begin{array}{r}5 \cdot 50 \\
5 \cdot 71 \\
11 \cdot 80 \\
3 \cdot 42 \\
5 \cdot 66\end{array}$ & $\begin{array}{l}5 \\
6 \\
7 \\
4 \\
5\end{array}$ & $\begin{array}{l}0.36 \\
0.46 \\
0.11 \\
0.49 \\
0.34\end{array}$ & $\begin{array}{l}(\text { EA) } \\
\text { EAn) } \\
\text { (EAAn) } \\
\text { ESAn) }\end{array}$ & $\begin{array}{l}1 \\
2 \\
1 \\
2\end{array}$ & $\begin{array}{l}0.21 \\
6.09 \\
2.08 \\
0.05\end{array}$ & $\begin{array}{l}1 \\
1 \\
1 \\
1\end{array}$ & $\begin{array}{l}0.65 \\
0.01 \\
0.15 \\
0.82\end{array}$ \\
\hline
\end{tabular}

An = Angina.

$E=$ Exposure

$\mathrm{S}=$ Smoking

$\mathrm{A}=$ Age . 
by (CEA). Another aspect of the class of log linear models used here is that they are hierarchical, which means that the specification of the three way interaction term (CEA) automatically includes in the model all the two way ((CE) (EA) (CA)) and marginal effects ((E) (A) (C)). Model 1 in table 3 suggests that the cell frequencies can be accounted for by taking into account all the two way (and one way) interactions between $(C),(E),(A)$, and cigarette smoking (S). The value of $\chi^{2}$ is not statistically significant, indicating that this model fits the data quite well.

The importance of a particular effect in the model can be assessed by deleting it from the base model and recalculating the predicted cell frequencies and chi square value. The difference in the chi square values is also a chi square value whose statistical significance indicates the importance of the deleted effect. If the difference between the two chi square values is not statistically significant then the effect deleted is not required to account adequately for the observed data. The interaction between age and exposure (EA) is omitted from model 2 . The difference in the value of chi square between models 1 and 2 is not statistically significant, indicating that the (EA) interaction may be omitted from the model. Hence, the independence of exposure and age is confirmed.

Model 3 omits the interaction between exposure and chest pain, (CE). The difference in the chi square values between models 2 and 3 is statistically significant, indicating that the observed data cannot be adequately modelled without taking the relationship between exposure and chest pain into account.
Table 3 also shows that no higher order interaction involving chest pain and exposure reached statistical significance, thus indicating that the relationship between chest pain and exposure does not depend on age or on smoking, respectively.

Table 4 analyses the relationships among exposure, smoking, age, and angina (An). Again, the exposure age interaction (EA) is not statistically significant, but theinteraction between exposure and angina (EAn) is. The three way interactions between exposure, angina, and smoking (EAnS) and age (EAnA), respectively, are not significant, indicating that the relationship between exposure and angina is not conditional on either age or smoking.

Analysis of chest pain based on duration of exposure (table 5) shows that the relationship between exposure and chest pain does not depend on the duration of exposure (D). The exposure-chest pain effect is statistically significant, but the two way relationship between duration and chest pain is not. Similarly, the relationship between angina and exposure (table 6) is significant $\left(\chi^{2}=11 \cdot 11,2 \mathrm{df}, \mathrm{p}\right.$ $=0.004, n=152$ ), but this relationship does not depend on the duration of exposure $\left(\chi^{2}=2 \cdot 17,2 \mathrm{df}\right.$, $\mathrm{p}=0.34, \mathrm{n}=152$ ).

The interaction between exposure and raised blood pressure as determined by history or physical examination, or both, is not significant $\left(\chi^{2}=2 \cdot 07,1\right.$ df, $\mathrm{p}=0 \cdot 15, \mathrm{n}=154)$. The interaction between length of time on the job and raised blood pressure, on the other hand, is highly significant $\left(\chi^{2}=12 \cdot 78,1\right.$ df, $p=0.004, n=154$ ). Within both exposed and control groups, the prevalence of raised blood pressure among workers with at least 10 years at the

Table 5 Relationships: chest pain, length of time on job (duration), exposure

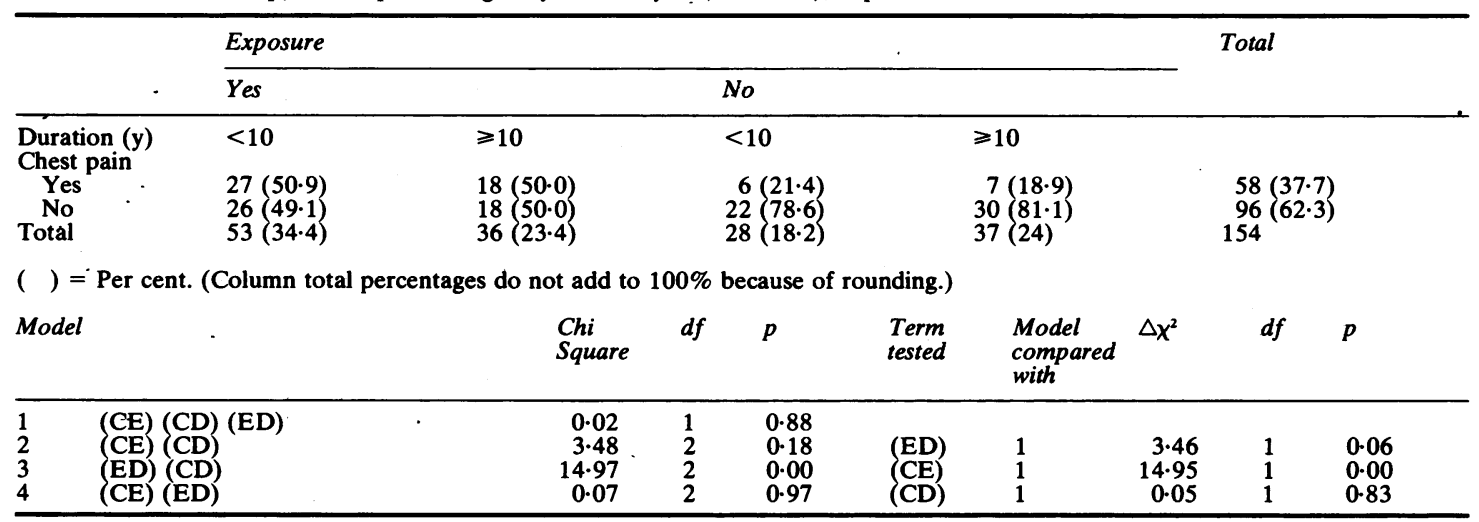

$\mathrm{D}=$ Duration on the job (years).

$E=$ Exposure

$\mathrm{C}=$ Chest pain 
Table 6 Relationships: angina, length of time on job, and exposure

\begin{tabular}{|c|c|c|c|c|c|}
\hline & \multicolumn{4}{|l|}{ Exposure } & \multirow[t]{2}{*}{ Total } \\
\hline & Yes & & No & & \\
\hline Duration (y) & $<10(y)$ & $\geqslant 10(y)$ & $<10(y)$ & $\geqslant 10(y)$ & \\
\hline $\begin{array}{l}\text { Yes } \\
\text { Maybe } \\
\text { No } \\
\text { Total }\end{array}$ & $\begin{array}{r}4(7 \cdot 7) \\
8(15 \cdot 4) \\
40(76 \cdot 9) \\
52(34 \cdot 2)\end{array}$ & $\begin{array}{r}3(8 \cdot 6) \\
8(22 \cdot 8) \\
24(68 \cdot 6) \\
35(23 \cdot 0)\end{array}$ & $\begin{array}{c}0(0) \\
0(0) \\
28(100) \\
28(18 \cdot 4)\end{array}$ & $\begin{array}{c}3(8 \cdot 1) \\
2(5 \cdot 4) \\
32(86 \cdot 5) \\
37(24 \cdot 3)\end{array}$ & $\begin{array}{c}10(6 \cdot 6) \\
18(11 \cdot 8) \\
124(81 \cdot 6) \\
152\end{array}$ \\
\hline
\end{tabular}

( ) = Per cent. (Column total percentages do not add to $100 \%$ because of rounding.)

Table 7 Electrocardiogram results

\begin{tabular}{lccc}
\hline ECG interpretation & Exposed & Control & Total \\
\hline Abnormal & $6(6 \cdot 7)$ & $3(4 \cdot 6)$ & $9(5 \cdot 8)$ \\
Borderline & $4(4 \cdot 4)$ & $0(0)$ & $4(2 \cdot 6)$ \\
Normal & $79(88 \cdot 8)$ & $62(95 \cdot 4)$ & $141(91 \cdot 6)$ \\
Total & 89 & 65 & 154 \\
$x^{2}=3 \cdot 39,2$ df, $\mathrm{p}=0.18$ & & \\
\hline
\end{tabular}

( ) $=$ Per cent. (Column total percentages do not add to $100 \%$ because of rounding.)

Table 8 Relationships: coronary heart disease, length of time on job (duration), exposure

\begin{tabular}{llllll}
\hline & \multicolumn{1}{l}{ Exposure } & & Total \\
\cline { 2 - 5 } & Yes & \multicolumn{1}{l}{ No } & \\
\hline Duration $(\mathrm{y})$ & $<10$ & $\geqslant 10$ & $<10$ & $\geqslant 10$ & \\
CHD: & $14(26 \cdot 9)$ & $13(37 \cdot 1)$ & $0(0)$ & $6(16 \cdot 2)$ & $33(21 \cdot 7)$ \\
Yes & $38(73 \cdot 1)$ & $22(62 \cdot 8)$ & $28(100)$ & $31(83 \cdot 8)$ & $119(78 \cdot 3)$ \\
No & $52(34 \cdot 2)$ & $35(23 \cdot 0)$ & $28(18 \cdot 4)$ & $37(24 \cdot 3)$ & 152 \\
Total & &
\end{tabular}

( ) $=$ Per cent. (Column total percentages do not add to $100 \%$ because of rounding.)

plant $(50 \%$ (18) exposed, $45.9 \%$ (17) control) exceeded that among those with less than 10 years (28.3\% (15) exposed, $10.7 \%$ (3) control). But the mean age of the former group ( $44 \cdot 8$ years, exposed; $46 \cdot 6$ years, control) is greater than that of the latter $(33 \cdot 1$ years, exposed; $27 \cdot 8$ years, control).

The number of abnormal or borderline ECGs did not differ significantly between the exposed and control group (table 7). The number of workers with a "coronary" ECG (4 exposed, 0 control) was too small for useful analysis.

Based on our definition of CHD (possible/definite angina, coronary ECG, or history of MI or a combination of these), the prevalence of CHD in the exposed group (table 8 ) is significantly greater than that in the control group $\left(\chi^{2}=12 \cdot 29.1 \mathrm{df}, \mathrm{p}=\right.$ $0.005, \mathrm{n}=152$ ).

This relationship does not appear to depend on length of time on the job $\left(\chi^{2}=3.61,1 \mathrm{df}, p=0.058\right.$, $n=152$ ). If the criteria are made more specific by the exclusion of possible angina, however, the relationship between exposure and CHD is no longer statistically significant $\left(\chi^{2}=2 \cdot 52,1 \mathrm{df}, \mathrm{p}=0 \cdot 11, \mathrm{n}\right.$ $=152)$. Eleven of the $87(12.6 \%)$ exposed workers compared with four of the $65(6.2 \%)$ controls had "definite" CHD. Similarly the association with duration of exposure is not significant $\left(\chi^{2}=1 \cdot 47,1 \mathrm{df}, \mathrm{p}\right.$ $=0 \cdot 23, n=152)$. Five of the 11 exposed with "definite" CHD and all four controls with this designation had worked at least 10 years at the plant.

The exercise stress test results in exposed individuals were equivocal in three and normal in 21 ; two of the tests were submaximal. Of those with equivocal results, one had a history of a previous MI while of those with normal results, one had a history of a coronary artery bypass procedure and one had changes consistent with a previous inferior wall MI on resting ECG.

\section{Biological monitoring}

Mean urinary aromatic amine and blood methaemoglobin levels were higher in the exposed 


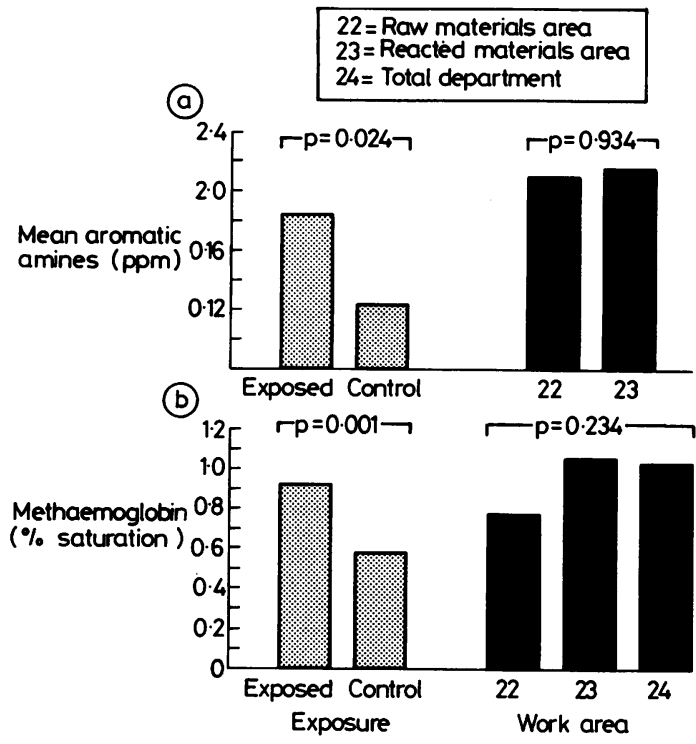

Fig 1 Biological monitoring results compared in workers exposed and unexposed, and exposed in different work areas (raw materials versus reacted materials versus entire department).
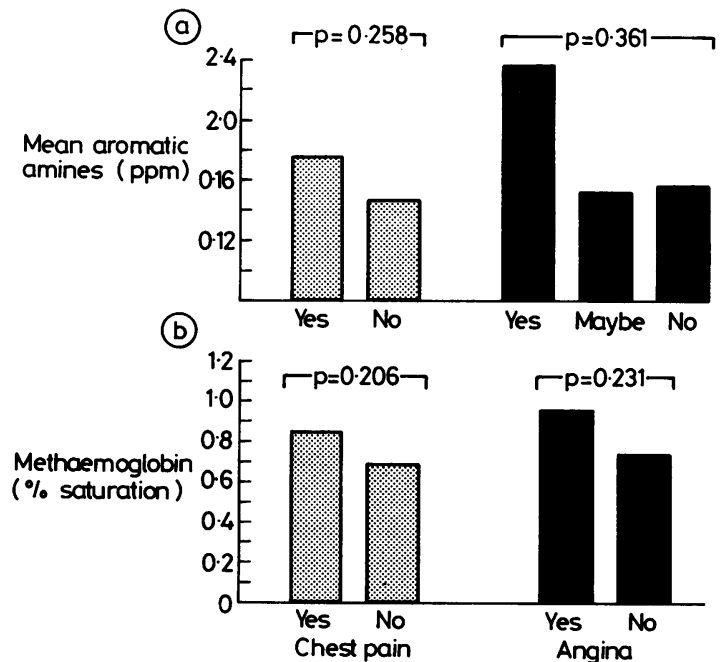

Fig 2 Biological monitoring results compared in workers with and without chest pain and angina.

group than in the controls. Within the exposed group, levels did not differ significantly between those exposed to raw materials and those exposed to reacted products (fig 1$)$. The prevalence of neither chest pain nor angina correlate significantly with the biological measures of exposure (fig 2). There is no association between an abnormal ECG and raised*

\footnotetext{
*" Raised", is defined as $\geqslant 1$ SD above the mean.
}

aromatic amine $\left(\chi^{2}=0.34,1 \mathrm{df}, \mathrm{p}=0.56, \mathrm{n}=137\right)$ or methaemoglobin $\left(\chi^{2}=1.48,2 \mathrm{df}, \mathrm{p}=0.48\right)$ levels.

\section{Environmental monitoring}

Based on an eight hour time weighted average (TWA), air borne levels of $\mathrm{CS}_{2}$, aniline, $o$-toluidine, and nitrobenzene were below the threshold limit values (TLV) established by the American Conference of Government Industrial Hygienists. ${ }^{18}$ Maximum measured exposures were as follows: $\mathrm{CS}_{2}$, $0.67 \mathrm{ppm}$; aniline, $0.27 \mathrm{ppm}$; nitrobenzene, 0.06 $\mathrm{ppm}$; and $o$-toluidine, $0.26 \mathrm{ppm}$. The highest levels occurred in the handling of raw materials. Grab samples for $\mathrm{H}_{2} \mathrm{~S}$ analysis showed a maximum measured exposure of 3-4 ppm.

\section{Discussion}

The data presented above show a significantly higher prevalence of chest pain, both cardiac and non-cardiac, in workers exposed to $\mathrm{CS}_{2}$ and methaemoglobin forming aromatic amines, compared with a control group. The association of chest pain and angina with exposure retains its statistical significance after controlling for age and cigarette smoking. CHD as defined by the presence of possible or definite angina or history of MI or coronary ECG, or a combination of these, is significantly correlated with exposure. This relationship loses its statistical significance, however, when workers with possible angina are excluded from the analysis, probably due to the small number with definite angina ( 7 exposed, 3 control). These findings are consistent with those reported by Hernberg et al, ${ }^{2}$ Tolonen, ${ }^{3}$ and Sakurai ${ }^{4}$ in viscose rayon workers. Other results were not consistent with the findings of these authors, however. Unlike Sakurai, ${ }^{4}$ we found no association between angina or CHD and duration of exposure of 10 or more years. It is possible that allowing for longer latency by selecting as our cut off point 20 rather than 10 years of exposure would have shown an association with duration, but the small numbers did not permit useful analysis. Tiller, however, observed an excess death rate from CHD in workers with less than 10 years' exposure to $\mathrm{CS}_{2}{ }^{1}{ }^{1}$

The numbers with a coronary ECG and a history of MI were too small for valid comparison. Tolonen et al reported a relative risk of 1.4 for coronary ECGs in $\mathrm{CS}_{2}$-exposed workers, and risks of 2.8 for non-fatal MIs and 4.8 for fatal MIs. ${ }^{3}$ A follow up study ${ }^{5}$ showed that 29 of 343 exposed and 11 of the 343 non-exposed had died from CHD ( $p<0.01)$. We did not evaluate mortality. Hernberg et $a^{2}$ and Tolonen $\mathrm{et}^{\mathrm{al}} \mathrm{l}^{3}$ found an association between expos- 
ure to $\mathrm{CS}_{2}$ and rise in blood pressure, but our results showed no such relationship; instead age appeared to be the critical variable associated with high blood pressure.

The number of abnormal ECGs in our exposed group was more than twice that in the control group and although the difference was not significant, it does suggest an association with exposure. Exercise stress tests were not done in controls; hence, comparative analysis was not possible. In no case was the stress test clearly positive. Of those 24 with equivocal or normal results, however, two had CHD by history and one by resting ECG. Other authors have found no significant difference in the results of exercise tests in exposed compared with control groups. $^{23}$

The present study shows no evidence of an acute effect on the heart of workplace exposures. Biological monitoring provided objective evidence of exposure to methaemoglobin forming aromatic amines, but neither chest pain nor ECG abnormalities correlated with mean levels of urine aromatic amines or blood methaemoglobin. This finding is consistent with the relatively low levels of exposure observed.

Weaknesses of the present study include (1) small numbers, (2) a lack of representative monitoring data, and (3) the inadequacy of available noninvasive diagnostic tools for CHD. Exposures experienced by workers during the first 20 years of the plant's operation cannot be reconstructed accurately since before this study, personal sampling was not carried out and area sampling was not undertaken routinely. Since the late 1970 s, engineering controls have been installed to reduce environmental exposures to toxins, so the results of the present industrial hygiene survey. in all likelihood do not reflect past exposure.

Non-invasive diagnostic tools available for field studies include cardiovascular history, resting ECG, and exercise stress tests but these tools are inadequate to diagnose CHD. ${ }^{319-22}$ The subjective nature of histories can be minimised but not eliminated. In the present case it is possible that bias was introduced by the occurrence of fatal myocardial infarctions 22 months before the study in two individuals who were current or former employees in $A$. The resting ECG is an insensitive method for the diagnosis of CHD and the diagnostic value of the exercise stress test depends on the population studied and a proper correlation of results with other clinical data. ${ }^{21} 22$ In a population in which the underlying prevalence of CHD is high the number of false positives is low and the number of false negatives high. In a population in which the underlying prevalence is low, the opposite is true. ${ }^{22}$ In the present study the population was mixed in that it consisted of both young and middle age men with varying degrees of expected risk for heart disease. One of the purposes of the stress test was better to define the population and the role of $\mathrm{CS}_{2}$ exposure in modifying the risk.

Although we had hoped to separate individual and additive or multiplicative effects of exposure to two groups of potential cardiotoxins by looking for acute and chronic effects of exposure, we were unable to do so. We were also unable to evaluate independently the possible effects of $\mathrm{H}_{2} \mathrm{~S}$ and $\mathrm{CS}_{2}$ on the heart. In the present study $\mathrm{H}_{2} \mathrm{~S}$ was evolved from one of the production processes and accompanies exposures to $\mathrm{CS}_{2}$ in other industrial settings. For example, the reaction of $\mathrm{CS}_{2}$ and sulphric acid in the production of the rayon fibre in the viscose rayon textile industry results in the evolution of $\mathrm{H}_{2} \mathrm{~S}$ gas. ${ }^{24}$ The role of $\mathrm{H}_{2} \mathrm{~S}$ in the CHD observed in viscose rayon textile workers has not been defined.

Despite its shortcomings, the present study suggests an association between CHD and chronic exposure to $\mathrm{CS}_{2}$ in a group of industrial workers in whom such an association has not been reported previously. To document better the observed association and to explore further the question of combined effects of $\mathrm{CS}_{2}$ and methaemoglobin formers (as well as $\mathrm{H}_{2} \mathrm{~S}$ possibly), would require the investigation of a larger group of rubber chemical workers exposed to the materials. A mortality study would provide more definitive data on the chronic effects of exposure; a morbidity study on both acute and chronic effects or exposure.

We are greatly indebted to Clifford A Johnson, corporate medical director of Goodyear Tyre and Rubber Company and to Jim Ward and Jack DeLong, president and health and safety chairman (respectively) of Local 8-277 of the Oil, Chemical and Atomic Workers International Union for their help and support. We also appreciate the help of Mary Hyde, Robert Gempel, Howard Hartley, Rose Goldman, and Patti Hill.

\section{References}

' Tiller JR, Schilling RSF, Morris JN. Occupational toxic factor in mortality from coronary heart disease. $\mathrm{Br}$ Med $J$ 1968;iv:407-11.

${ }^{2}$ Hernberg S, Partanen T, Nordman CH, Sumari P. Coronary heart disease among workers exposed to carbon disulphide. $\mathrm{Br}$ $J$ Ind Med 1970;27:313-25.

${ }^{3}$ Tolonen M, Hernberg S, Nurminen M, Tiitola K. A follow-up study of coronary heart disease in viscose rayon workers exposed to carbon disulphide. Br J Ind Med 1975;32:1-10.

4 Sakurai H. A morbidity study of viscose rayon workers exposed to carbon disulphide. $\mathrm{Br} \mathrm{J}$ Ind Med 1982;39:39-44.

s Tolonen M, Nurminen M, Hernberg S. Ten-year coronary mor- 
tality of workers exposed to carbon disulfide. Scand J Works, Environ Health 1979;5:109-14.

- Biro GP. Myocardial blood flow and $\mathrm{O}_{2}$ supply after dextran haemodilution and methaemoglobinemia in the dog. Cardiovasc Res 1979;8:459-68.

${ }^{7}$ Guarino A, Arciello G. Histological study on coronary arteries in chronic experimental carbon disulfide poisoning. Folia Med (Napoli) 1954;37:1022-44.

${ }^{8}$ Wronska-Nofer T, Szendzikowski S, Laurman W. The effect of carbon disulfide and atherogenic diet on the development of atherosclerotic changes in rabbits. Atherosclerosis 1978;31:33-9.

${ }^{9}$ Wronska-Nofer T, Parke M. Influence of carbon disulfide on metabolic processes in the aorta wall: study of the rate of cholesterol synthesis and the rate of influx of ${ }^{14} \mathrm{C}$-cholesterol from the serum into the aorta wall. Int Arch Occup Environ Health 1978;42:63-8.

${ }^{10}$ Visconti E, Vidakovic A, Cavalleri A, Rezman I, Maugeri U, Visnjic V. Fibrinolytic activity in young workers exposed to carbon disulfide. In: Brieger $\mathrm{H}$, Teisinger J, eds. Toxicology of carbon disulphide. Proceedings of a symposium. New York: Excerpta Medica Foundation, 1967:128-32.

"Tolonen M, Hernberg S, Nordman C, Goto S, Sugimoto K, Baba T. Angina pectoris, electrocardiographic findings and blood pressure in Finnish and Japanese workers exposed to carbon disulfide. Int Arch Occup Environ Health 1976;37:249-64.

${ }_{12}$ Rose GA. The diagnosis of ischaemic heart pain and intermittent claudication in field surveys. Bull WHO 1962;27:645-58.

${ }^{13}$ Bishop YMM, Fienberg SE, Holland PW. Discrete multivariate analysis. Cambridge, Mass: MIT Press, 1975.

${ }^{14}$ Fienberg SE. The analysis of cross-classified categorical data. Cambridge, Mass: MIT Press, 1977.

is Gokhale DV, Kullback S. The information in contingency tables. New York: Marcel Dekker, Inc, 1978.

${ }^{16}$ Haberman SJ. Analysis of qualitative data. Vol 1. Introductory topics. New York: Academic Press, 1978.

17 Goodman LA. Analyzing qualitative/categorical data. Cambridge, Mass: Abt Books, 1979.

${ }^{18}$ American Conference of Government Industrial Hygienists Threshold limit values for chemical substances and physical agents in the workroom environment with intended changes for 1981. Cincinnati, Ohio: ACGIH, 1981:19-31.

${ }^{19}$ Kuller LH. Epidemiology of cardiovascular diseases: current perspectives. Am J Epidemiol 1976;104:425-56.

${ }^{20}$ Borer JS, Brensike JF, Redwood DR, et al. Limitations of the electrocardiographic response to exercise in predicting coronary artery disease. $N$ Engl $J$ Med 1975;293:367-71.

${ }^{21}$ Hartley LH. Value of clinical exercise testing. $N$ Engl $J$ Med 1975;293:400-1.

${ }^{22}$ Epstein SE. Limitations of electrocardiographic exercise testing. N Ensl J Med. 1979:301:264-5.

${ }^{23}$ Weiner DA, Ryan TJ, McCabe CH, et al. Exercise stress testing. Correlations among history of angina, ST-segment response and prevalence of coronary-artery disease in the coronary artery surgery study (CASS). $N$ Engl $J$ Med 1979;301:230-5.

${ }^{24}$ Hamilton A, Hardy HL. Industrial toxicology. Littleton, Mass: John Wright PSG, Inc, 1982:406. 